\title{
Viewpoint: Selection for improved drought response in cool-season grasses
}

\author{
DOUGLAS A. JOHNSON AND KAY H. ASAY
}

\author{
Authors are plant physiologist and research geneticist, USDA-ARS, Forage and Range Research Lab., Utah State \\ Univ., Logan 84322-6300.
}

\begin{abstract}
Water limits the establishment, growth, and production of coolseason grasses on semiarid rangelands, and plant improvement programs for these areas must be capable of screening breeding lines for response to drought. Although many techniques to evaluate various morphological and physiological characteristics have been proposed, few have been used successfully in plant breeding programs. Consequently, a need exists to identify and develop rapid, reliable screening techniques that can assess integrated plant response to drought in large plant populations. Improved seedling emergence has been achieved in Russian wildrye [Psathyrostachys juncea (Fischer) Nevski] by selecting for emergence from a deep seeding depth and long coleoptiles. Water uptake by roots is critical, and screening for enhanced seedling root growth in coolseason grasses offers considerable promise. In spite of the important role that stomatal control has in regulating plant water loss, limited success has been achieved in incorporating desirable stomatal characteristics into improved grass cultivars. Although osmotic adjustment appears beneficial in some crop species, more research is needed before cool-season grasses should be selected based on osmotic adjustment. Selection for improved water-use efficiency in cool-season grasses based on carbon isotope discrimination is a promising approach. Successful incorporation of these various traits into improved cool-season grass cultivars necessitates close cooperation between breeders and physiologists.
\end{abstract}

Key Words: carbon isotope discrimination, genetic variation, heritability, osmotic adjustment, plant breeding, plant improvement, seedling emergence, water loss, water uptake, water-use efficiency

Water deficits limit the growth and production of cool-season grasses on semiarid rangelands. Adaptations that allow coolseason grasses to avoid or withstand the influence of drought must be considered in plant improvement programs. Although many techniques are available to evaluate morphological and physiological characteristics related to drought adaptations, few have been successfully used in plant breeding programs. Most of this reseach has involved annual crop species such as wheat (Triticum aestivum L.), corn (Zea mays L.), sorghum (Sorghum bicolor [L.] Moench), and rice (Oryza sativa L.) (Blum 1988, 1989; Srivastava et al. 1987; Ludlow and Muchow 1990; Richards 1991; White and Singh 1991). Very little research has focused specifically on cool-season forage grasses (Wright 1975, Johnson 1980, Johnson et al. 1981, Asay and Johnson 1983a, Frank et al. 1987). In this review we examine selection criteria and techniques for improving response to drought for cool-season perennial grasses and synthesize pertinent information available from annual crops. The most promising directions of research to pursue in this important area for cool-

Cooperative investigations of the USDA-ARS and the Utah Agricultural Experiment Station. Journal Paper 4264.

Manuscript accepted 11 Nov. 1992. season grasses are identified and discussed.

\section{The Challenge}

The diverse characteristics that allow plants to adapt to drought can be categorized as follows: (1) drought escape, (2) dehydration avoidance, and (3) dehydration tolerance (Turner 1986). Because drought escape refers to "the ability of a plant to complete its life cycle before serious soil and plant water deficits develop," this classification category does not strictly apply to perennial species, which extend their life cycle beyond more than 1 growing season. Consequently, only the classification categories of dehydration avoidance and tolerance are relevant to perennial cool-season grasses.

Any heritable characteristic or combination of characteristics could be used to select breeding lines for improved response to drought. Although researchers have proposed many possible characteristics that could be used in selection, few have been successfully used to improve agronomic performance under drought. This lack of success probably results from a combination of factors including limited opportunities for multidisciplinary researchers to work closely with plant breeders; a poor understanding of integrated plant response to drought; complex genetic control of multiple mechanisms involved in plant performance; difficulty in selecting a target environment where the genetic variation in the breeding population is not masked by environmental effects; and lack of repeatable, precise screening techniques for use in a plant breeding program.

Few locations throughout the world have multidisciplinary team efforts where physiologists work closely with breeders to improve the performance of cool-season forage grasses under drought. As a result, most breeders rely on empirical selection procedures to identify superior plants. However, understanding the physiological basis of plant response to drought would allow breeders to screen for components of drought resistance. As Ludlow and Muchow (1990) indicated, traits to improve drought response too often are based only on theory, laboratory studies, or correlations. In addition, the manner in which these traits are inherited and their influence on field performance seldom have been documented. Without increased, closer interaction between forage breeders and physiologists, progress for improving drought response in coolseason grasses will be slow.

Much is known of individual morphological, anatomical, and physiological characteristics that enable plants to grow and survive under drought (Hsiao 1973; Fischer and Turner 1978; Turner and Kramer 1980; Turner and Begg 1978, 1981; Schulze 1988; Ludlow 1989). Relatively little is known about the genetic mechanisms that condition these characteristics. Austin (1989) emphasized that no single plant attribute is likely the primary determinant of successful growth and survival in water-limited environments. Consequently, more attention should be focused on understanding integrated 
plant responses to drought.

Another important factor to consider is the interaction of metabolic pathways involved between the level of plant organization where the particular plant characteristics are being selected and the plant level at which improvement is desired (Passioura 1981). Possible characteristics for selection can be categorized according to the molecular, membrane, organelle, cellular, tissue, organ, whole plant, and community levels of plant organization. Passioura (1981) noted that improved plant response at the plant community level can be achieved more effectively by selecting at the whole plant or organ level rather than at the molecular or membrane level. In most instances, as the span increases between the level of plant organization where selection occurs and where the desired response is evaluated, the number of interacting genetic factors involved in successfully transferring this characteristic increases markedly.

During the last 100 years, the economic value of a wide range of agronomically important crops has increased subsantially due to both improved cultural practices and the breeding of new crop cultivars. Most of these breeding programs have involved selection at the whole plant or organ level and have been tied closely to field evaluation. Improving the drought response of cool-season grasses should involve similar approaches and incorporate newly emerging technology.

Opportunities for genetic advance, as indicated by the magnitude of genetic variances and heritability values, typically decline as the severity of drought increases. This was demonstrated in experiments with alfalfa (Medicago sativa L.), the RS wheatgrass hybrid [Elytrigia repens (L.) Nevski X E. spicata (Pursh) D.R. Dewey], and crested wheatgrass [Agropyron desertorum (Fisch. ex Link) Schult.] under both field and greenhouse line-source sprinkler systems (Rumbaugh et al. 1984, Asay and Johnson 1990). As is typical in most plant breeding situations, trait means, genetic variances, and heritabilities declined markedly as less irrigation water was applied. Genetic differences in the drier sections of the plots were masked by differences in the microenvironment, which indicates that selection would be more effective if made at intermediate rather than extreme levels of drought.

Mahon (1983) also observed that the existence of significant genetic variability in a physiological character within a single environment does not ensure that selection will isolate plants with superior expression of the character over a range of environments. Drought varies temporally as well as in duration and intensity, which makes identification of a target environment for selection extremely difficult. Mahon (1983) also concluded that many studies of genetic variability for various physiological characteristics are based on performance in controlled environments and usually represent potential expression of the characteristic. The expression of this potential may be greatly diminished or entirely masked by other limiting factors in the field environment. Kramer (1980) emphasized the critical role of the field environment in influencing the expression of genetic potential of selected characters through effects on rates and duration of physiological processes.

Levitt (1964), Hanson (1972), Cooper 1974), and White and Singh (1991) stressed the importance of developing reliable methods of screening plants for the desired characteristics. Johnson (1980) and Johnson et al. (1981) stated that such techniques should (1) enable researchers to assess plant performance at the critical developmental stage, (2) be completed in a relatively short time, (3) use small quantities of plant material, and (4) be capable of screening large populations.

Several procedures have been proposed to evaluate characteristics associated with plant water relations (Turner 1981); most, however, are too laborious and time-consuming to use in a plant breeding program. In addition, these characteristics typically fluctuate throughout the day or during the season, vary with degree of drought and plant age, and may not provide an integrated measure of plant response. An obvious need exists to develop rapid, reliable screening techniques that can evaluate integrated plant response to drought in large numbers of breeding lines.

\section{Improved Seedling Emergence}

The ability of seedlings to become established is crucial for stand success (Benjamin 1990, Ries and Svejcar 1991); and for many species, advantages gained at the seedling stage are retained through the mature plant stage (TeKrony and Egli 1991). Harper (1977) provided a useful definition of establishment, defining it as the time "when the seedlings have expanded a photosynthetic surface and are theoretically capable of pursuing an existence independent of their seed reserves." Seedlings are particularly susceptible to drought because they have low photosynthetic capacity and only limited carbon and nutrient reserves. Rapid germination, early root initiation, and rapid root extension belp seedlings compete with weedy species and avoid drought caused by evaporative water losses in the upper soil layers. In addition, vigorous growth or dry matter accumulation during the early, cool part of the growing season increases water-use efficiency. Although the relationship between seedling emergence and improved response to drought is somewhat indirect, rapid seedling emergence and development has important implications concerning adaptation to drought in cool-season grasses.

"Seedling vigor" is a useful, but somewhat vague term that often is used to describe the general aggressiveness of seedling emergence (Kneebone 1972, McKell 1972). Kneebone (1972) defined seedling vigor as the ability to grow rapidly in the seedling stage, thereby increasing the probability of stand establishment. Improving seedling emergence may make it possible to place seed at a deeper soil depth where soil water conditions may favor germination.

Seedling vigor in many cool-season grasses is related to seed size; large-seeded strains emerge sooner from deeper planting depths and grow more rapidly than do small-seeded strains (Murphy and Arny 1939; Plummer 1943; Rogler 1954; Kalton et al. 1959; Tossell 1960; Lawrence 1963; Hunt and Miller 1965; Trupp and Carlson 1971; Asay and Johnson 1980, 1983b; Berdahl and Barker 1984). Consequently, seed weight has been recommended as an easily measured, reliable selection criterion for improving seedling vigor. A number of researchers, however, found differences in seedling vigor independent of seed weight and recommended the inclusion of additional criteria such as seedling emergence from a deep planting depth (Kalton et al. 1959; Tossell 1960; Lawrence 1963; Asay and Johnson 1980, 1983b) and coleoptile length (Hunt and Miller 1965, Berdahl and Barker 1984).

Some cool-season grasses have been bred and selected successfully for improved emergence. Lawrence (1963) selected Russian wildrye [Psathyrostachys juncea (Fischer) Nevski] breeding lines for heavy seed weight and subsequently screened their emergence from a 5.0-cm planting depth. After 4 cycles of selection, the Russian wildrye cultivar 'Swift' was released (Lawrence 1979), which has improved establishment capability and produces large plants in the establishment year. Asay et al. (1985a) screened breeding lines of Russian wildrye for their ability to emerge from deep seeding depths and developed the cultivar 'Bozoisky-Select.' Asay et al. (1985b) evaluated seed weight, emergence from deep seeding depths, and agronomic characteristics of breeding lines of crested wheatgrass [Agropyron desertorum (Fisch. ex Link) Schult. $\mathrm{x} A$. cristatum (L.) Gaert.] and released the cultivar 'Hycrest.' Hycrest has demonstrated excellent seedling emergence and stand establishment characteristics in field trials throughout the Intermountain Region(Asayet al. 1986). A more recent Russian wildrye 
cultivar 'Mankota,' which was selected primarily for dry matter yield along with coleoptile length and emergence from a $5-\mathrm{cm}$ depth, has demonstrated improved stand establishment capability (Berdahl et al. 1992). Results from the above studies conclusively show that improved seedling emergence can be achieved in Russian wildrye and crested wheatgrass by selecting for high seed weight, emergence from deep seed placement, and coleoptile length.

\section{Water Extraction}

The amount of water available to a plant critically depends on soil water uptake by roots. Many researchers have examined root growth, development, and water transport in the past 15 years, and this research has been reviewed by Taylor and Klepper (1978), Feldman (1984), Boyer (1985), and Passioura (1988). Perennial plants from dry regions generally have increased root to shoot ratios (Caldwell 1975). These ratios indicate the large amount of carbon and nutrient allocations to root systems, and also reflect root turnover and mortality rates in these environments. Many plants modify their rooting behavior during drought by allocating a relatively greater proportion of total carbon and nutrients to root growth at the expense of shoot growth (Brouwer 1966, Davidson 1969). Curtailing shoot growth permits additional root growth for subsequent exploration for soil water, a beneficial trade-off only if sufficient water is available deeper in the soil profile.

Plummer (1943) attributed success or failure of establishment of 12 range grasses to total root development before summer drought. Crested wheatgrass, the most successful range grass, had the longest roots and the most roots at the seedling stage. Rapid and extensive root development was essential in the early growth and survival of seedlings of Russian wildrye and crested wheatgrass on western rangelands (Hassanyar and Wilson 1978), permitting them to successfully compete with cheatgrass (Bromus tectorum L.), an introduced weedy annual species (Harris 1967, Reichenberger and Pyke 1990, Aguirre and Johnson 1991a).

Forage yield of 6 cool-season grasses under drought was related directly to the volume of soil exploited by roots (Garwood and Sinclair 1979). The ability to extract water from a deep soil depth was associated closely with an extensive root system. Caldwell and Richards (1986) showed that mature crested wheatgrass [Agropyron desertorum (Fisch. ex Link) Schult.] had a greater competitive effectiveness against Artemisia tridentata spp. vaseyana (Rydb.) Beetle than mature bluebunch wheatgrass [ Pseudoroegneria spicata (Pursh) Love] because of a greater rooting density, partially due to thinner roots.

Hurd (1974) documented the importance of an extensive root system for maximizing wheat yields in western Canada. Root growth of wheat genotypes that had been sclected mainly for grain yield was observed in boxes with inclined glass faces (Hurd 1964, 1968). Selecting parents and breeding lines at final test stages that had rapid root penetration, large total root length, and a high proportion of total root weight below $30 \mathrm{~cm}$ when drought was imposed (Hurd et al. 1972b) led to the development of 2 wheat cultivars (Hurd et al. 1972a, 1973). Passioura (1981), however, cautioned that a large, extensive root system may be beneficial only in environments where water is available deep in the soil profile and is replenished each year, and all the water in the profile is not extracted by existing roots. For other environments where ample water is not available deep in the soil profile each year, Passioura $(1972,1976)$ suggested that early, slow root growth that conserved water at the vegetative phase would ensure subsequent water availability during the critical grain-filling period. This latter approach probably is not applicable to most cool-season forages whose vegetative growth is of prime importance. Also, in rangeland situations any water saved by the desirable forage species could be used by competing weedy species.
O'Toole and Bland (1987) comprehensively reviewed genotypic variation for a wide range of root characteristics in crop plants and summarized the information available for each crop species. Their review indicated the existence of genotypic variation for many root characteristics. Furthermore, heritabilities appear relatively high, which suggests that most root characteristics can be effectively manipulated through breeding and selection. OToole and Bland (1987) cited 6 examples of successful genetic shifts in rooting function and were optimistic that additional progress in breeding for root characteristics will be made in the future.

Genetic variation for various seedling root characteristics has been reported in cool-season grasses. Root growth under low temperatures varied among populations of orchardgrass (Dactylis glomerata L.) (Finn and Mack 1964); timothy (Phleum pratense L.) (Mack and Finn 1970); and bluebunch wheatgrass (Harris and Goebel 1976). The study reported by Harris and Goebel (1976) was noteworthy because it involved 45 collections from sites as far south as Nogales, Ariz., and as far north as Fairbanks, Alaska. Seedling root growth at $2^{\circ} \mathrm{C}$ ranged from 1.4 to $11.9 \mathrm{~mm}$ at 21 days. Although differences in seed size and the seed production environment may have explained some of the variation, significant genetic variation is apparently present for root growth at low temperature.

Techniques that Larsson (1982) used for oats (Avena sativa L.) may be well suited for screening for enhanced seedling root growth in cool-season grasses. Larsson used a morpho-physiological drought resistance index that related root length to leaf area of 10-day-old seedlings growing in a controlled environment and compared these to a check cultivar. This laboratory procedure gave highly repeatable rankings of oat genotypes and was used to select for increased root length to leaf area ratio in oats. Larsson and Gorny (1988) showed that the selected lines exhibited high yield and high drought tolerance. They concluded that the drought resistance index appears to be a promising method for increasing drought resistance of oats.

Root morphology of seedlings plays a critical role in the establishment of grasses (Hyder et al. 1971) and may be an important selection criterion for improving seedling response to drought. Hoshikawa (1969) examined 219 species of 88 genera within the Gramineae and classified seedlings into 6 types of seedling root morphology. Most cool-season grasses exhibited a festucoid-type of seedling, which had transitionary-node (seminal) root development, lacked or had little mesocotyl (subcoleoptile internode) elongation, and had no mesocotylar roots. Seedling root morphological development has been examined in various cool-season grasses (Newman and Moser 1988, Aguirre and Johnson 1991b, Ries and Hofmann 1991). Johnson and Aguirre (1991) found that the competitive nature of cheatgrass seedlings was primarily associated with seminal roots that had high branching density, long lateral growth, and external-external links. Additional work is required before these potentially useful characteristics of root morphology can be incorporated into a plant improvement program.

The labor and space required to screen for mature root system size make it difficult to screen large numbers of breeding lines. Clarke (1987), however, suggested these techniques may be valuable in identifying potential parental types and in reducing the number of crosses that a breeder has to make and evaluate.

Despite the difficulties encountered in evaluating root characteristics of mature plants, some indirect techniques appear to have promise for incorporation into a breeding program. One such technique involves banding the herbicide metribuzin at a certain depth in the soil (Robertson et al. 1985). The faster the roots of a cowpea (Vigna unguiculata [L.] Walp.) plant reached the herbi- 
cide, the sooner it began exhibiting effects of the herbicide. Metribuzin also was banded vertically to determine rates of lateral root growth. Robertson et al. (1985) recommended use of this technique to screen the root growth rates of large populations in the field. They indicated that this method provided moderate resolution of genotypic differences in rooting and would be useful in identifying parental materials for a breeding program. Subsequent selection among progeny from crosses would probably require a method with greater resolution. A similar technique used iodine-131 to detect rooting depth of shrubs and grasses (Abbott et al. 1991).

Water uptake also can be indirectly screened with infrared thermometry, which assesses plant canopy temperatures (Blum et al. 1982). Generally, plants with lower temperatures under stress had better yields because of their greater root growth and water extraction from the soil. Ludlow and Muchow (1990), however, emphasized that infrared thermometer measurements can be influenced by factors such as wind conditions, cloudiness, saturation deficit of the air, and degree of canopy cover. Furthermore, higher plant canopy temperatures might be beneficial when water availability later in the growing season is critical (Hatfield et al. 1987). Cooler canopy temperatures might also identify plants that simply use the most water, without regard for the efficiency in water use.

O'Toole and Bland (1987) emphasized that a breeding and selection program for root characteristics should (1) clearly define the problem and identify the most limiting function of the root system; (2) formulate a working hypothesis and choose critical root parameters; (3) develop appropriate screening procedures and determine the existence, level, and nature of the genetic variation; (4) hybridize the parental lines and select among their progeny; and (5) evaluate resultant genotypes in the field and verify or reject the working hypothesis. Environmental factors also can alter attributes of the root system (Carson 1974).

\section{Reduced Water Loss}

One of the most general mechanisms for regulating water loss in plants is through reductions in leaf area, either by leaf senescence or shedding. A reduction in leaf area in forages, however, is not generally desirable unless essential for plant survival. Other mechanisms that reduce water loss include (Schulze 1988): thickening of the epidermal cell wall and the cuticle, development of leaf hairs, leaf orientation and movement away from the sun, leaf rolling, stomatal closure, and development of epicuticular wax. These latter 2 characteristics will be examined for their possible application within a cool-season grass improvement program.

Because of the importance of stomata in controlling water loss and carbon uptake in plants, considerable effort has been directed at understanding stomatal function and examining stomatal response to the environment. Numerous researchers have evaluated the influence of drought on stomatal response and have speculated on particular attributes that could allow more effective control over water loss. Many of the methods available for screening stomatal characters and practical considerations of their use are presented by Jones (1979).

Genetic variation in stomatal frequency and stomatal length has been reported for smooth bromegrass (Walton 1974, Tan and Dunn 1975) and perennial ryegrass (Lolium perenne L.) (Wilson 1971). Genetic variances for these characteristics were mostly additive, and heritabilities were relatively high. Stomata in diploid plants of perennial ryegrass were shorter than in tetraploid plants (Speckmann et al. 1965). Jones (1987), however, emphasized that breeders seeking to improve response to drought through stomatal characteristics should emphasize changes in stomatal conductance, which integrate the effects of individual components of stomatal aperture.

Walton (1974) detected genetic variation for stomatal conduc- tance in 3 ploidy levels of smooth bromegrass (Bromus inermis Leysser). Selection for stomatal conductance was relatively ineffective in perennial ryegrass, which may have been due in part to a negative correlation between stomatal length and frequency (Wilson 1972). Gay (1986) employed a diffusion porometer to identify perennial ryegrass seedlings with high and low leaf water conductance. These differences in stomatal conductance persisted in the older plants (Gay 1989), an indication that stomatal conductance was sufficiently stable to allow effective selection. Field evaluation is required to determine whether these differences in stomatal conductance affect yield and other agronomic characteristics.

In spite of the critical role that stomatal control supposedly has in regulating plant water loss, little success has been achieved in incorporating desirable stomatal characteristics into improved crop cultivars. Jones (1987) attributed the lack of success to (1) redundancy of mechanisms in plants that compensate for the particular selected response, (2) environmental influences on stomatal response, (3) the large degree of phenotypic plasticity in stomatal characteristics, and (4) an incomplete understanding of the physiological and ecological roles of stomata. Despite the potential benefits of particular stomatal characteristics and responses and the existence of genetic variability for some of these traits, more research is needed before stomatal characteristics can be recommended as definitive selection criteria for cool-season grasses.

The influence of canopies on lowered leaf conductance and transpiration also must be considered. Because of boundary layer effects, Jones (1987) suggested that breeding to minimize water loss through stomatal changes is likely to be most beneficial in tall or widely spaced crops. Jarvis and McNaughton (1986) indicated that stomata of crops with aerodynamically rough canopies (such as the sparse bunchgrass, shrub, and forb vegetation of western rangelands), which have a high boundary layer conductance, exert more control over transpirational water loss than aerodynamically smooth canopies (such as a solid grass sward in the Midwest), which have a low boundary layer conductance. Because short, uniform grass swards are not as well coupled with the atmosphere compared to taller, less uniform vegetation, there would be proportionately less benefit in reducing transpiration through changes in stomatal conductance in grass swards than in widely spaced bunchgrasses growing on western rangelands.

Epidermal wax or glaucousness increases grain yield in sorghum (Jordan et al. 1983); wheat (Johnson et al. 1983, Richards 1984); and barley (Hordeum vulgare L.) (Baenziger et al. 1983). The effects on yield are due primarily to increased reflectance of radiation and subsequently lower tissue temperature (Richards et al. 1986) and to decreased water loss through the cuticle (Jordan et al. 1984). Jefferson et al. (1989b) did not find a consistent relationship between epicuticular wax production and cuticular transpiration in crested wheatgrass and alfalfa, nor was increased epicuticular wax associated with increased forage yield. In another study, Jefferson et al. (1989a) evaluated the effect of epicuticular wax in an intermediate wheatgrass hybrid (Thinopyrum intermedium (Host) Barkworth and D.R. Dewey X T. intermedium-acutum D.R. Dewey pers. commun.) and an interspecific hybrid of crested wheatgrass [induced tetraploid Agropyron cristatum (L.) Gaertner s. lat. X $A$. desertorum (Fisch. ex Link) Schultes], and Altai wildrye (Leymus angustus (Trin.) Pilger Dewcy]. Glaucousness influenced the water relations of these grasses, but did not affect forage yield. Although of benefit to grain yield in annual crops, enhanced epicuticular wax does not appear to be of benefit in increasing forage yield in cool-season grasses. Epicuticular wax may, however, be an important characteristic in long-term persistence of cool-season perennial grasses. 


\section{Osmotic Adjustment}

Osmotic adjustment is another potential selection criterion for improving plant response to drought in various annual crops (e.g., Ludlow and Muchow 1988, 1990; Blum 1988, 1989). Osmotic adjustment is usually defined as an increase in osmotic pressure of cell sap resulting from more solute molecules per cell rather than from a lower cell volume (Munns 1988). Some physiologists use the term "osmoregulation," but Turner (1986) and Munns (1988) suggested that osmoregulation is not an appropriate term for higher plants.

Osmotic adjustment involves the accumulation of solutes in response to drought and results in maintenance of stomatal opening and photosynthesis, postpones leaf rolling and senescence, and maintains root growth under water-limited conditions in many annual crops (Turner and Jones 1980, Morgan 1984, Turner 1986). Although osmotic adjustment will not eliminate drought-related reductions in photosynthesis and growth, it appears to play an important role in survival of the developing apex and leaves (Turner 1986). Ludlow and Muchow (1990) suggested that the ability to osmotically adjust may be marginally preferred over deep roots and high root length density because osmotic adjustment has minimal costs (McCree 1986), is induced only by limited water, and is lost after stress is relieved. The dry matter required for root growth, however, competes with forage growth.

Wheat plants with high osmotic adjustment extracted more water from the soil and produced more dry matter and higher grain yield during drought than did those with low osmotic adjustment (Morgan 1984, Morgan and Condon 1986, Morgan et al. 1986, Blum and Pnuel 1990). However, increased grain yields in sorghum selections with high osmotic adjustment were attributed primarily to a greater harvest index and greater re-translocation of preanthesis dry matter rather than increased water use or dry matter production (Ludlow et al. 1990, Santamaria et al. 1990). Consequently, it may not be possible to use osmotic adjustment to select cool-season grasses for increased forage production.

Genetic variation for osmotic adjustment has been found in many crop species including wheat, sorghum, pearl millet [Pennisetum glaucum (L.) R. Br.], cotton (Gossypium hirustum L.), rice, and pigeonpea [Cajanus cajan (L.) Huth] (Ludlow and Muchow 1990). Adequate genetic variability and the evidence that a single recessive gene conditions high osmotic adjustment in wheat (Morgan 1991) should facilitate selection for this trait. Although Morgan (1983) suggested that psychrometric procedures for evaluating osmotic adjustment could be used in screening moderate numbers of advanced breeding lines and parents within a plant improvement program, these procedures are quite laborintensive and may not be capable of screening large numbers of lines in the early phases of a breeding program. An alternative may be to use indirect methods such as canopy temperature and leaf rolling (Blum 1989). Consequently, incorporating osmotic adjustment into a breeding program may depend on the development of rapid, reliable methods to measure osmotic adjustment.

Although osmotic adjustment varies considerably within coolseason grasses and at least in perennial ryegrass is amenable to genetic selection, selection did not improve leaf growth under drought in perennial ryegrass (Thomas and Evans 1989). Even though Ludlow and Muchow (1990) believe that osmotic adjustment can improve grain yield of various annual crops, additional research is required to determine the utility of osmotic adjustment as a selection criterion for improved response to drought in coolseason grasses.

\section{Water-Use Efficiency}

The amount of water required for plant growth and production has been studied for many years. The classic review of Briggs and Shantz (1913) on the water requirement of plants cited studies conducted in the late 1600 's (Woodward 1699). This early work on plant water requirements was followed by studies concerning the efficiency of water use by various plants. Sinclair et al. (1984) noted that the term water-use efficiency has been used to describe a wide range of various observations covering diverse times and process scales and suggested the term should be defined according to these factors. In this paper we distinguish between instantaneous calculations of water-use efficiency (WUE $E_{i}$ ) obtained from gas exchange measurements of the amount of carbon dioxide assimilated $(A)$ per unit of water transpired $(E)$ and longer-term calculations of wateruse efficiency (WUE) obtained by comparing biomass produced to the unit of water required to produce that biomass.

Considerable research has been conducted concerning the limitations to efficient water use in crop production and improving crop WUE (Stone 1975, Taylor et al. 1983, Stanhill 1986). Stanhill (1986) indicated that numerous climatic, plant, and soil factors influence WUE. Climatic factors influence WUE through rainfall distribution, vapor pressure deficit of the air, and carbon dioxide concentration. Plant characteristics can also affect WUE through photosynthetic capacity, stomatal behavior, and leaf characteristics, such as size, structure, and foliage orientation. Both chemical and physical characteristics of the soil can directly or indirectly influence WUE through soil water content, infiltration rates, soil surface features, water movement, availability of soil water, impedance of root penetration, and nutrient status. Stanhill (1986) discusses the economic aspects of commercial crop production in determining optimum levels of WUE.

Determining WUE typically involves pot-weighing studies conducted in a greenhouse and evaluating $W^{-} E_{i}$ involves measuring plant gas exchange. Monitoring water use in pots is laborious and time-consuming, and only a few breeding lines can be evaluated by this method. Similarly, although instruments now make it possible to rapidly and reliably measure photosynthesis and transpiration, these instantaneous values must be measured throughout the life of the plant to obtain an integrated value of WUE. Consequently, these methods of determining WUE usually are not feasible for a breeding and selection program.

Research the past few years has indicated that WUE in plants that fix carbon (C) by the $\mathrm{C}_{3}$ pathway is related to the stable $\mathrm{C}$ isotope composition of their tissues (Rundel et al. 1989), a fact that may be useful in a plant breeding program. Stable isotopes are nonradioactive forms of elements found naturally in the earth and its atmosphere. Carbon has 2 stable isotopes. The ${ }^{12} \mathrm{C}$ isotope comprises about $99 \%$ of the $C$ in the earth and its atmosphere, and the ${ }^{13} \mathrm{C}$ form comprises only a small fraction of the $\mathrm{C}$ present. The carbon isotope composition can be measured by grinding and combusting plant tissue and analyzing the $\mathrm{CO}_{2}$ by an isotoperatioing mass spectrometer.

Many physical and biological processes prefer or discriminate against certain stable isotopes. Because plants discriminate against ${ }^{13} \mathrm{C}$, they typically contain less ${ }^{13} \mathrm{C}$ than would be expected based on its natural abundance in the atmosphere. This discrimination is particularly large for plants that fix carbon by the $C_{3}$ pathway because ribulose bisphosphate carboxylase-oxygenase (Rubisco) discriminates against ${ }^{13} \mathrm{CO}_{2}$ during fixation. This discrimination against ${ }^{13} \mathrm{C}$ by $\mathrm{C}_{3}$ plants has been used to differentiate them from plants that fix carbon by the $\mathrm{C}_{4}$ or Crassulacean acid metabolism (CAM) pathways (e.g., Bender 1971).

Farquhar et al. (1982) and Farquhar and Richards (1984) proposed that ${ }^{13} \mathrm{C}$ discrimination $(\Delta)$ in $C_{3}$ plants is related to leaf intercellular $\mathrm{CO}_{2}$ concentration ( $\mathrm{c}_{\mathrm{i}}$ ). Farquhar et al. (1989) reviewed the large body of data that support this relationship. Farquhar et al. (1988) attributed the association between WUE and $\Delta$ to inde- 
pendent linkages through $c_{i}$, one of which involves stomatal conductance (Farquhar et al. 1989). As a plant becomes water limited, stomata eventually undergo at least some closure. If this stomatal closure restricts transpirational loss to an extent that exceeds reductions in photosynthesis, $c_{i}$ would be reduced and WUE would be increased. However, further decrease in stomatal conductance increases the relative concentration of ${ }^{13} \mathrm{CO}_{2}$ in the interior of the leaf, thereby reducing the ability of Rubisco to discriminate against ${ }^{13} \mathrm{CO}_{2}$. Consequently, $\Delta$ decreases as the water deficit increases. High $\Delta$ values resulting from elevated $c_{i}$ levels are associated with low WUE, whereas low $\Delta$ values resulting from low $c_{i}$ are associated with high WUE (Hubick et al. 1988, Farquhar et al. 1989). Consistent negative associations between WUE and $\Delta$ have been reported under contrasting soil water treatments (Farquhar et al. 1988 ). Because $C$ is continually being fixed by a leaf, $\Delta$ provides a long-term indication of $c_{i}$ and integrates $c_{i}$ over the life of the tissue analyzed. Because $c_{i}$ is affected by diffusional and biochemical processes that contribute to changes in $W^{2} E_{i}, \Delta$ may be useful in selecting plants for increased WUE (Farquhar and Richards 1984).

Most research concerning $\Delta$ has involved $C_{3}$ annual crop species. In a study with cool-season forage grasses, Johnson et al. (1990) examined the relationship between $\Delta$ and WUE in greenhouse-grown crested wheatgrass and Altai wildrye. They found that $\Delta$ was negatively correlated with WUE in the shoots of crested wheatgrass $\left(r=-0.73^{* *}\right)$ and Altai wildrye $\left(r=-0.81^{* *}\right)$.

Johnson et al. (1990) also reported on a field study with 29 vegetatively propagated clones of crested wheatgrass grown along a line-source sprinkler system that applied variable amounts of water. That study showed that $\Delta$ declined as less water was applied. The $\Delta$ of crested wheatgrass clones differed significantly at the 2 peak-season harvests, and rankings of the clones were generally consistent across water levels. The clone by harvest interaction was not significant, suggesting that clones were ranked consistently for $\Delta$ from one harvest to the next.

In studies conducted by Johnson et al. (1990), broad-sense heritability for $\Delta$ approached 0.50 in analyses of data combined over harvests and water levels. Genetic variances and broad-sense heritabilities for $\Delta$ were generally greater at the high and intermediate water levels than at the low water application. These results suggest that ample genetic variation is present and heritabilities are high enough in crested wheatgrass to effectively select for $\Delta$ response.

Greenhouse studies of Read et al. (1991) showed that $\Delta$ of crested wheatgrass decreased with drought. Across water levels, $\Delta$ was inversely related to WUE $\left(r=-0.95^{* *}\right)$ or shoot WUE $(r=$ $\left.-0.89^{* *}\right)$. Although $\Delta$ and $c_{i}$ of individual clones were correlated positively at each water level, the expected differences between $\Delta$ classes in $\Delta$, WUE $E_{i}$, and shoot WUE occurred only under drought. A low $\Delta$ under drought was associated with greater shoot dry weight, $W U E_{i}$, and shoot WUE. In field experiments with the same clones, values for $\Delta$ and $c_{i}$ were negatively associated with both WUE and WUE $E_{i}$ within each of 2 water levels (Read et al. 1992). Across both water levels, $\Delta$ was negatively correlated with WUE $\mathrm{E}_{\mathrm{i}}(r$ $\left.=-0.93^{* *}\right)$ and with WUE $\left(r=-0.98^{* *}\right)$. Consequently, selection for low $\Delta$ apparently would lead to improved WUE in crested wheatgrass.

Johnson and Bassett (1991) examined $\Delta$ and WUE in crested wheatgrass, tall fescue (Festuca arundinacea Schreb.), orchardgrass, and perennial ryegrass. In a greenhouse experiment, WUE was generally higher in accessions with low $\Delta$ than those with high $\Delta$ under both well-watered and drought conditions. Leaf water potential, solute potential, and turgor pressure were also higher in accessions with low $\Delta$, which indicates that water status was more favorable for growth. In field studies, significant differences in $\Delta$ were observed among accessions within species. The environment by accession interaction was not significant, indicating that acces- sion differences in $\Delta$ were generally consistent across environments. Consequently, it should be possible to utilize $\Delta$ to select for improved WUE in cool-season grasses.

For forage species, forage yield is of primary importance in identifying superior breeding lines. Consequently, the relationship between forage yield and $\Delta$ is of concern. Across 3 water levels for peak-season forage harvests in a rainout shelter experiment, simple correlation coefficients $(r)$ between forage yield and $\Delta$ were $0.59 * *$ during 1986 and $0.80^{* *}(\mathrm{df}=85$ ) during 1987 (Johnson et al. 1990). This suggests that selection for increased WUE (low $\Delta$ ) may lead to decreases in forage yield. However, this relationship is apparent only when data were combined across the 3 water levels. When the association was evaluated within a water level, $r$ values were not significant and ranged from 0.07 to 0.33 for 1986 and 0.09 to 0.44 for 1987 . This was similar to the pattern observed in the ficld pot study of Read et al. (1992) where shoot dry weight increased with $\Delta$ $\left(r=0.83^{* *}, \mathrm{df}=10\right)$ across the 2 water levels, but was not correlated within either the well-watered $(r=-0.71, \mathrm{df}=4)$ or droughted $(r=$ $-0.10, \mathrm{df}=4)$ treatments. In the greenhouse pot study of Read et al. (1991), shoot dry weight of crested wheatgrass increased with $\Delta$ in the well-watered treatment $\left(r=0.77^{*}, \mathrm{df}=7\right)$, but not in the drought treatment $(r=-0.14, \mathrm{df}=7)$. Although we might logically expect selection for low $\Delta$ to be accompanied by a decrease in forage yield in water-limited environments, our results to date have not shown a consistent relationship. A negative relationship between genetic variation for $\Delta$ and forage yield under a uniform water-limited environment is essential for $\Delta$ to be a useful selection criterion to improve WUE. Additional research is needed to clarify the relationship between $\Delta$ and forage yield in cool-season grasses.

\section{Combinations of Characteristics}

No single plant characteristic can identify plants with improved response to drought. Ludlow and Muchow (1990) ranked the merit of various traits in helping plants tolerate intermittent and terminal drought in modern and subsistence agricultural settings. They suggested that traits appear to be linked in strategies varying from extreme avoidance to extreme tolerance. Understanding these linkages is fundamental in integrating plant traits into a selection index. Models such as those of McCree et al. (1990) and Johnson et al. (1991) provide a framework for evaluating how combinations of various plant characteristics influence plant water status and growth. Modelling may usefully bridge physiology and breeding into integrated programs of plant improvement (Shorter et al. 1991). Additional research involving selection indices of multiple traits and plant modelling is required to more efficiently develop improved crops for water-limited environments.

\section{Summary}

Considerable research has focused on identifying plant characteristics that are associated with adaptation to drought. Choosing which traits can be effectively screened and exhibit sufficient genetic variability for selection demands a long-term commitment and close interaction between breeders and physiologists. Most of the information about those plant traits for improved response to drought has been obtained from annual grain crops. This information may not be directly applicable to cool-season grasses, where the desired end product is forage rather than grain and whose growth habit is perennial instead of annual. For cool-season grasses, the main improvement in response to drought to date has involved more rapid seedling establishment, which allows the plant to take better advantage of seasonally available water. Promise also exists for selecting for root characteristics and for improved water-use efficiency through the use of carbon isotope discrimination. Although the challenges involved in improving response to drought in cool-season grasses are great, so are the benefits. 


\section{Literature Cited}

Abbott, M.L., L. Fraley, Jr., and T.D. Reynolds. 1991. Root profiles of selected old desert shrubs and grasses in disturbed and undisturbed soils. Environ. Exp. Bot. 31:165-178.

Aguirre, L., and D.A. Johnson. 1991a. Influence of temperature and cheatgrass competition on seedling development of two bunchgrasses. J. Range Manage. 44:347-354.

Aguirre, L., and D.A. Johnson. 1991b. Root morphological development in relation to shoot growth in seedlings of four range grasses. J. Range Manage. 44:341-346.

Asay, K.H., D.R. Dewey, F.B. Gomm, W.H. Horton, and K.B. Jensen. 1986. Genetic progress through hybridization of induced and natural tetraploids in crested wheatgrass. J. Range Manage. 39:261-263.

Asay, K.H., D.R. Dewey, F.B. Gomm, D.A. Johnson, and J.R. Carlson. 1985a. Registration of 'Bozoisky-Select' Russian wildrye. Crop Sci. 25:575-576.

Asay, K.H., D.R. Dewey, F.B. Gomm, D.A. Johnson, and J.R. Carison 1985b. Registration of 'Hycrest' crested wheatgrass. Crop Sci. 25:368-369.

Asay, K.H., and D.A. Johnson. 1980. Screening for improved stand establishment in Russian wild ryegrass. Can. J. Plant Sci. 60:1171-1177.

Asay, K.H., and D.A. Johnson. 1983a. Breeding for drought resistance in range grasses. Iowa State J. Res. 57:441-455.

Asay, K.H., and D.A. Johnson. 1983b. Genetic variability for characters affecting stand establishment in crested wheatgrass. J. Range Manage. 36:703-706.

Asay, K.H., and D.A. Johnson. 1990. Genetic variances for forage yield in crested wheatgrass at six levels of irrigation. Crop Sci. 30:79-82.

Austin, R.B. 1989. Prospects for improving crop production in stressful environments, p. 235-248. In: H.G. Jones, T.J. Flowers, and M.B. Jones (ed.), Plants under stress. Soc. Exp. Biol. Seminar Ser. 39. Cambridge Univ. Press, Cambridge.

Baenziger, P.S., D.M. Wesenberg, and R.C. Sicher. 1983. The effects of genes controlling barley leaf and sheath waxes on agronomic performance in irrigated and dryland environments. Crop Sci. 23:116-120.

Bender, M.M. 1971. Variations in the ${ }^{13} \mathrm{C} /{ }^{12} \mathrm{C}$ ratios of plants in relation to the pathway of photosynthetic carbon dioxide fixation. Phytochem. 10:1239-1244.

Benjamin, L.R. 1990. Variation in time of seedling emergence within populations: a feature that determines individual growth and development. Adv. Agron. 44:1-25.

Berdahl, J.D., and R.E. Barker. 1984. Selection for improved seedling vigor in Russian wild ryegrass. Can. J. Plant Sci. 64:131-138.

Berdahl, J.D., R.E. Barker, J.F. Karn, J.M. Krupinsky, R.J. Haas, D.A. Tober, and I.M. Ray. 1992. Registration of 'Mankota' Russian wildrye. Crop Sci. 32:1073.

Blum, A. 1988. Plant breeding for stress environments. CRC Press, Boca Raton, Fla.

Blum, A. 1989. Breeding methods for drought resistance, p. 197-215. In H.G. Jones, T.J. Flowers, and M.B. Jones (ed.), Plants under stress. Soc Exp. Biol. Seminar Ser. 39. Cambridge Univ. Press, Cambridge.

Blum, A., J. Mayer, and G. Golan. 1982. Infrared thermal sensing of plant canopies as a screening technique for dehydration avoidance in wheat. Field Crops Res. 57:137-146.

Blum, A., and Y. Pnuel. 1990. Physiological attributes associated with drought resistance of wheat cultivars in a Mediterranean environment. Aust. J. Agr. Res. 41:799-810.

Boyer, J.S. 1985. Water transport. Annu. Rev. Plant Physiol. 36:473-516. Briggs, L.J., and H.L. Shantz. 1913. The water requirement of plants. I1. A review of the literature, p. 1-96. USDA Bur. Plant Ind. Bull. 285.

Brouwer, R. 1966. Root growth of grasses and cereals, p. 153-166. In: F.L. Milthorpe and J.D. Ivins (ed.), The growth of cereals and grass. Butterworths, London.

Caldwell, M.M. 1975. Primary production of grazing lands, p. $41-73$. In. J.P. Cooper (ed.), Photosynthesis and productivity in different environments. Cambridge Univ. Press, London.

Caldwell, M.M., and J.H. Richards. 1986. Competing root systems: morphology and models of absorption, p. 251-273. In: T.J. Givnish (ed.), On the economy of plant form and function. Cambridge Univ. Press, Cambridge.

Carson, E.W. (ed.). 1974. The plant root and its environment. Univ. Press of Virginia, Charlottesville.

Clarke, J.M. 1987. Use of physiological and morphological traits in breeding programs to improve drought resistance of cereals, p. 171-189. In: J.P. Srivastava, E. Proceddu, E. Acevedo, and S. Varma (ed.), Drought tolerance in winter cereals. John Wiley and Sons, Chichester.
Cooper, J.P. 1974. The use of physiological criteria in grass breeding, $p$. 95-102. Welsh Plant Breeding Sta. Rep. Aberystwyth

Davidson, R.L. 1969. Effects of soil nutrients and moisture on root/shoot ratios in Lolium perenne L. and Trifolium repens L. Ann. Bot. 33:571-577.

Farquhar, G.D., J.R. Ehleringer, and K.T. Hubick. 1989. Carbon isotope discrimination and photosynthesis. Annu. Rev. Plant Physiol. Plant Mol. Biol. 40:503-537.

Farquhar, G.D., K.T. Hubick, A.G. Condon, and R.A. Richards. 1988. Carbon isotope fractionation and plant water-use efficiency, p. 21-40. In: P.W. Rundel, J.R. Ehleringer, and K.A. Nagy (ed.), Stable isotopes in ecological research. Ecological Studies Vol. 68. Springer-Verlag, N.Y.

Farquhar, G.D., M.H. OLeary, and J.A. Berry. 1982. On the relationship between carbon isotope discrimination and the intercellular carbon dioxide concentration in leaves. Aust. J. Plant Physiol. 9:121-137.

Farquhar, G.D., and R.A. Richards. 1984. Isotopic composition of plant carbon correlates with water-use efficiency of wheat genotypes. Aust. J. Plant Physiol. 11:539-552.

Feldman, L.J. 1984. Regulation of root development. Annu. Rev. Plant Physiol. 35:223-242.

Finn, B.J., and A.R. Mack. 1964. Differential response of orchardgrass varieties (Dactylis glomerata L.) to nitrogen and phosphorus under controlled soil temperature and moisture conditions. Soil Sci. Soc. Amer. Proc. 28:782-785.

Fischer, R.A., and N.C. Turner. 1978. Plant productivity in the arid and semiarid zones. Annu. Rev. Plant Physiol. 29:277-317.

Frank, A.B., R.E. Barker, and J.D. Berdahl. 1987. Water-use efficiency of grasses grown under controlled and field conditions. Agron. J. 79:541-544.

Garwood, E.A., and J. Sinclair. 1979. Use of water by six grass species. 2. Root distribution and use of soil water. J. Agr. Sci. 93:25-35.

Gay, A.P. 1986. Variation in selection for leaf water conductance in relation to growth and stomatal dimensions in Lolium perenne L. Ann. Bot. $57: 361-369$.

Gay, A.P. 1989. Assessment of the response to selection for leaf water conductance in Lolium perenne. Ann. Bot. 64:593-598.

Hanson, A.A. 1972. Breeding of grasses, p. 36-52. In: V.B. Younger and C.M. McKell (ed.), The biology and utilization of grasses. Academic Press, N.Y.

Harper, J.L. 1977. Population biology of plants. Academic Press, London. Harris, G.A. 1967. Some competitive relationships between Agropyron spicatum and Bromus tectorum. Ecol. Monogr. 37:89-111.

Harris, G.A., and C.J. Goebel. 1976. Factors of plant competition in seeding Pacific Northwest bunchgrass ranges. Bull. 820. Washington State Agr. Exp. Sta., Pullman.

Hassanyar, A.S., and A.M. Wilson. 1978. Drought tolerance of seminal lateral root apices in crested wheatgrass and Russian wildrye. J. Range Manage. 31:254-258.

Hatfield, J.L., J.E. Quisenberry, and R.E. Dilbeck. 1987. Use of canopy temperatures to identify water conservation in cotton germplasm. Crop Sci. 27:269-273.

Hoshikawa, K. 1969. Underground organs of the seedlings and the systematics of Gramineae. Bot. Gaz. 130:192-203.

Hsiao, T.C. 1973. Plant responses to water stress. Annu. Rev. Plant Physiol. 24:519-570.

Hubick, K.T., R. Shorter, and G.D. Farquhar. 1988. Heritability and genotype $\mathrm{x}$ environment interactions of carbon isotope discrimination and transpiration efficiency in peanut (Arachis hypogoea L.). Aust. J. Plant Physiol. 15:799-813.

Hunt, O.J., and D.G. Miller. 1965. Coleoptile length, seed size, and emergence in intermediate wheatgrass (Agropyron intermedium (Host) Beauv.). Agron. J. 57:192-195.

Hurd, E.A. 1964. Root study of three wheat varietics and their resistance to drought and damage by soil cracking. Can. J. Plant Sci. 44:240-248.

Hurd, E.A. 1968. Growth of roots of seven varieties of spring wheat at high and low moisture levels. Agron. J. 60:201-205.

Hurd, E.A. 1974. Phenotype and drought tolerance in wheat. Agr. Meteorol. 14:39-55.

Hurd, E.A., L.A. Patterson, D. Mallough, T.F. Townley-Smith, and C.H. Owen. 1972a. Wascana, a new durum wheat. Can. J. Plant Sci. 52:687-688.

Hurd, E.A., T.F. Townley-Smith, D. Mallough, and L.A. Patterson. 1973. Wakooma durum wheat. Can. J. Plant Sci. 53:261-262.

Hurd, E.A., T.F. Townley-Smith, L.A. Patterson, and C.H. Owen. 1972b. Techniques used in producing Wascana wheat. Can. J. Plant Sci. $52: 689-691$. 
Hyder, D.N., A.C. Everson, and R.E. Bement. 1971. Seedling morphology and seeding failures with blue grama. J. Range Manage. 24:287-292.

Jarvis, P.G., and K.G. MeNaughton. 1986. Stomatal control of transpiration: scaling up from leaf to region. Adv. Ecol. Res. 15:1-49.

Jefferson, P.G., D.A. Johnson, and K.H. Asay. 1989a. Epicuticular wax production, water status and leaf temperature in Triticeae range grasses of contrasting visible glaucousness. Can. J. Plant Sci. 69:513-519.

Jefferson, P.G., D.A. Johnson, M.D. Rumbaugh, and K.H. Asay. 1989b. Water stress and genotypic effects on epicuticular wax production of alfalfa and crested wheatgrass in relation to yield and excised leaf water loss rate. Can. J. Plant Sci. 69:481-490.

Johnson, D.A. 1980. Improvement of perennial herbaceous plants for drought-stressed western rangelands, p. 419-433. In: N.C. Turner and P.J. Kramer (ed.), Adaptation of plants to water and high temperature stress. John Wiley and Sons, N.Y.

Johnson, D.A., and L. Aguirre. 1991. Effect of water on morphological development in seedlings of three range grasses: root branching patterns. J. Range Manage. 44:355-360.

Johnson, D.A., K.H. Asay, L.L. Tieszen, J.R. Ehleringer, and P.G. Jefferson. 1990. Carbon isotope discrimination: potential in screening coolseason grasses for water-limited environments. Crop Sci. 30:338-343.

Johnson, D.A., R.A. Richards, and N.C. Turner. 1983. Yield, water relations, gas exchange, and surface reflectances of near-isogenic wheat lines differing in glaucousness. Crop Sci. 23:318-325.

Johnson, D.A., M.D. Rumbaugh, and K.H. Asay. 1981. Plant improvement for semiarid rangelands: possibilities for drought resistance and nitrogen fixation. Plant and Soil 58:279-303.

Johnson, I.R., J.J. Melkonian, J.H.M. Thornley, and S.J. Riha. 1991. A model of water flow through plants incorporating shoot/root 'message' control of stomatal conductance. Plant Cell. Environ. 14:531-544.

Johnson, R.C., and L.M. Bassett. 1991. Carbon isotope discrimination and water use efficiency in four cool-season grasses. Crop Sci. 31:157-162.

Jones, H.G. 1979. Stomatal behavior and breeding for drought resistance, p. 407-428. In: H. Mussell and R.C. Staples (ed.), Stress physiology in crop plants. Wiley-Interscience, N.Y.

Jones, H.G. 1987. Breeding for stomatal characters, p. 431-443. In: E. Zeiger, G.D. Farquhar, and I.R. Cowan (ed.), Stomatal function. Stanford Univ. Press, Calif.

Jordan, W.R., R.L. Monk, F.R. Miller, D.T. Rosenow, L.E. Clark, and P.J. Shouse. 1983. Environmental physiology of sorghum. I. Environmental and genetic control of epicuticular wax load. Crop Sci. 23:552-558.

Jordan, W.R., P.J. Shouse, A. Blum, F.R. Miller, and R.L. Monk. 1984. Environmental physiology of sorghum. II. Epicuticular wax load and cuticular transpiration. Crop Sci. 24:1168-1173.

Kalton, R.R., R.A. DeLong, and D.S. McLeod. 1959. Cultural factors in seedling vigor of smooth bromegrass and othe forage species. Iowa State J. Sci. 34:47-80.

Kneebone, W.R. 1972. Breeding for seedling vigor, p. 90-100. In: V.B. Youngner and C.M. Mckell (ed.), The biology and utilization of grasses. Academic Press, N.Y.

Kramer, P.J. 1980. The role of physiology in crop improvement, p. 51-62. In: R.C. Staples and R.J. Kuhr (ed.), Linking research to crop production. Plenum Press, N.Y.

Larsson, S. 1982. A simple, rapid and non-destructive screening method useful for drought resistance breeding in oats (Avena sativa $\mathrm{L}$.). $\mathrm{Z}$. Pflanzenzucht. 89:206-221.

Larsson, S., and A.G. Gorny. 1988. Grain yield and drought resistance indices of oat cultivars in field rain shelter and laboratory experiments. $J$. Agron. Crop Sci. 161:277-286.

Lawrence, T. 1963. A comparison of methods of evaluating Russian wild ryegrass for seedling vigor. Can. J. Plant Sci. 43:307-312.

Lawrence, T. 1979. Swift, Russian wild ryegrass. Can. J. Plant Sci 59:515-518.

Levitt, J. 1964. Drought, p. 57-66. In: Forage plant physiology and soilrange relationships. Amer. Soc. Agron. Spec. Pub. 5. Madison, Wis.

Ludlow, M.M. 1989. Strategies of response to water stress, p. 269-281. In: K.H. Kreeb, H. Richter, and T.M. Hinckley (ed.), Structural and functional responses to environmental stresses. SPB Academic Publ., The Hague.

Ludlow, M.M., and R.C. Muchow. 1988. A critical evaluation of possibilities for modifying crops for higher production per unit rainfall, $p$. 179-211. In: F.R. Bidinger and C. Johansen (ed.), Drought research priorities for the dryland tropics. ICRISAT, Patancheru, India.

Ludlow, M.M., and R.C. Muchow. 1990. A critical evaluation of traits for improving crop yields in water-limited environments. Adv. Agron. 43:107-153
Ludlow, M.M., J.M. Santamaria, and S. Fukai. 1990. Contribution of osmotic adjustment to grain yield in Sorghum bicolor (L.) Moench under water-limited conditions. II. Water stress after anthesis. Aust. J. Agr. Res. 41:67-78.

Mack, A.R., and B.J. Finn. 1970. Differential response of timothy clonal lines and cultivars to soil temperature, moisture and fertility. Can. J. Plant Sci. 50:295-305.

Mahon, J.D. 1983. Limitations to the use of physiological variability in plant breeding. Can. J. Plant Sci. 63:11-21.

McCree, K.J. 1986. Whole-plant carbon balance during osmotic adjustment to drought and salinity stress. Aust. J. Plant Physiol. 13:33-43.

McCree, K.J., C.J. Fernandez, and R. Ferraz de Oliveira. 1990. Visualizing interactions of water stress responses with a whole-plant simulation model. Crop Sci. 30:294-300.

McKell, C.M. 1972. Seedling vigor and seedling establishment, p. 74-89. In: V.B. Youngner and C.M. McKell (ed.), The biology and utilization of grasses. Academic Press, N.Y.

Morgan, J.M. 1983. Osmoregulation as a selection criterion for drought tolerance in wheat. Aust. J. Agr. Res. 34:607-614.

Morgan, J.M. 1984. Osmoregulation and water stress in higher plants. Annu. Rev. Plant Physiol. 35:299-319.

Morgan, J.M. 1991. A gene controlling differences in osmoregulation in wheat. Aust. J. Plant Physiol. 18:249-257.

Morgan, J.M., and A.G. Condon. 1986. Water use, grain yield, and osmoregulation in wheat. Aust. J. Plant Physiol. 13:523-532.

Morgan, J.M., R.A. Hare, and R.J. Fletcher. 1986. Genetic variation in osmoregulation in bread and durum wheats and its relationship to grain yield in a range of field environments. Aust. J. Agr. Res. 37:449-457.

Munns, R. 1988. Why measure osmotic adjustment? Aust. J. Plant Physiol. 15:717-726.

Murphy, R.P., and C.A. Arny. 1939. The emergence of grass and legume seedlings planted at different depths in five soil types. J. Amer. Soc. Agron. 31:17-28.

Newman, P.R., and L.E. Moser. 1988. Seedling root development and morphology of cool-season and warm-season forage grasses. Crop Sci. 28:148-151.

O'Toole, J.C., and W.L. Bland. 1987. Genotpyic variation in crop plant root systems. Adv. Agron. 41:91-145.

Passioura, J.B. 1972. The effect of root geometry on the yield of wheat growing on stored water. Aust. J. Agr. Res. 23:745-752.

Passioura, J.B. 1976. Physiology of grain yield in wheat growing on stored water. Aust. J. Plant Physiol. 3:559-565.

Passioura, J.B. 1981. The interaction between the physiology and the breeding of wheat, p. 191-201. In: L.T. Evans and W.J. Peacock (ed.), Wheat science-today and tomorrow. Cambridge Univ. Press, London.

Passioura, J.B. 1988. Water transport in and to roots. Annu. Rev. Plant Physiol. Plant Mol. Biol. 39:245-265.

Plummer, A.P. 1943. The germination and early seedling development of twelve range grasses. J. Amer. Soc. Agron. 35:19-34.

Read, J.J., D.A. Johnson, K.H. Asay, and L.L. Tieszen. 1991. Carbon isotope discrimination, gas exchange, and water-use efficiency in crested wheatgrass clones. Crop. Sci. 31:1203-1208.

Read, J.J., D.A. Johnson, K.H. Asay, and L.L. Tieszen. 1992. Carbon isotope discrimination: relationship to yield, gas exchange, and wateruse efficiency in field-grown crested wheatgrass. Crop Sci. 32:168-175.

Reichenberger, G., and D.A. Pyke. 1990. Impact of early root competition on fitness components of four semiarid species. Oecologia 85:159-166.

Richards, R.A. 1984. Glaucousness in wheat, its effect on yield and related characteristics in dryland environments, and its control by minor genes, p. 447-45I. In: S. Sakamoto (ed.), Proc. 6th Int. Wheat Genetics Symp. Kyoto, Japan

Richards, R.A. 1991. Crop improvement for temperate Australia: future opportunities. Field Crops Res. 26:141-169.

Richards, R.A., H.M. Rawson, and D.A. Johnson. 1986. Glaucousness in wheat: its development and effect on water-use efficiency, gas exchange and photosynthetic tissue temperatures. Aust. J. Plant Physiol. $13: 465-473$

Ries, R.E., and L. Hofmann. 1991. Research observations: standardized terminology for structures resulting in emergence and crown placement of 3 perennial grasses. J. Range Manage. 44:404-407.

Ries, R.E., and T.J. Svejcar. 1991. The grass seedling: when is it established? J. Range Manage. 44:574-576.

Robertson, B.M., A.E. Hall, and K.W. Foster. 1985. A field technique for screening for genotypic differences in root growth. Crop Sci. 25:1084-1090.

Rogler, G.A. 1954. Seed size and seedling vigor in crested wheatgrass. Agron. J. 46:216-220. 
Rumbaugh, M.D., K.H. Asay, and D.A. Johnson. 1984. Influence of drought stress on genetic variances of alfalfa and wheatgrass seedlings. Crop Sci. 24:297-303.

Rundel, P.W., J.R. Ehleringer, and K.A. Nagy (eds.). 1989. Stable isotopes in ecological research. Ecological studies Vol. 68. Springer-Verlag, N.Y.

Santamaria, J.M., M.M. Ludlow, and S. Fukai. 1990. Contribution of osmotic adjustment to grain yield in Sorghum bicolor (L.) Moench under water-limited conditions. I. Water stress before anthesis. Aust. J. Agr. Res. 41:51-65.

Schulze, E.D. 1988. Adaptation mechanisms of noncultivated arid-zone plants: useful lessons for agriculture? p. 159-177. In: F.R. Bidinger and C. Johansen (ed.), Drought research priorities for the dryland tropics. ICRISAT, Patancheru, India.

Shorter, R., R.J. Lawn, and G.L. Hammer. 1991. Improving genotypic adaptation in crops-a role for breeders, physiologists and modellers. Exp. Agr. 27:155-175.

Sinclair, T.R., C.B. Tanner, and J.M. Bennett. 1984. Water-use efficiency in crop production. BioScience 34:36-40.

Speckmann, G.J., J. Post, Jr., and H. Dijkstra. 1965. The length of stomata as an indicator for polyploidy in rye-grasses. Euphytica 14:225-230.

Srivastava, J.P., E. Proceddu, E. Acevedo, and S. Varma (eds.). 1987. Drought tolerance in winter cereals. John Wiley and Sons, Chichester.

Stanhill, G. 1986. Water use efficiency. Adv. Agron. 39:53-85.

Stone, J.F. (ed.). 1975. Plant modification for more efficient water use. Elsevier Sci. Publ. Co., Amsterdam.

Tan, G.-Y., and G.M. Dunn. 1975. Stomatal length, frequency, and distribution in Bromus inermis Leyss. Crop Sci. 15:283-286.

Taylor, H.M., W.R. Jordan, and T.R. Sinclair (eds.). 1983. Limitations to efficient water use in crop production. Amer. Soc. Agron., Madison, Wis.

Taylor, H.M., and B. Klepper. 1978. The role of rooting characteristics in the supply of water to plants. Adv. Agron. 30:99-128.

TeKrony, D.M., and D.B. Egli. 1991. Relationship of seed vigor to crop yield: a review. Crop Sci. 31:816-822.

Thomas, H., and C. Evans. 1989. Effects of divergent selection for osmotic adjustment on water relations and growth of plants of Lolium perenne. Ann. Bot. 64:581-587.
Tossell, W.E. 1960. Early seedling vigour and seed weight in relation to breeding in smooth bromegrass, Bromus inermis Leyss. Can. J. Plant Sci. 40:268-280.

Trupp, C.R., and I.T. Carlson. 1971. Improvement of seedling vigor of smooth bromegrass (Bromus inermis Leyss.) by recurrent selection for high seed weight. Crop Sci. 11:225-228.

Turner, N.C. 1981. Techniques and experimental approaches for the measurement of plant water status. Plant and Soil 58:339-366.

Turner, N.C. 1986. Crop water deficits: a decade of progress. Adv. Agron. 39:1-51.

Turner, N.C., and J.E. Begg. 1978. Responses of pasture plants to water deficits, p. 50-66. In: J.R. Wilson (ed.), Plant relations in pastures. CSIRO, Melbourne, Australia.

Turner, N.C., and J.E. Begg. 1981. Plant-water relations and adaptation to stress. Plant and Soil 58:97-131.

Turner, N.C., and M.M. Jones. 1980. Turgor maintenance by osmotic adjustment: a review and evaluation, p. 155-172. In: N.C. Turner and P.J. Kramer (ed.), Adaptation of plants to water and high temperature stress. Wiley-Interscience, N.Y.

Turner, N.C., and P.J. Kramer (eds.). 1980. Adaptation of plants to water and high temperature stress. John Wiley and Sons, N.Y.

Walton, P.D. 1974. The genetics of stomatal length and frequency in clones of Bromus inermis and the relationships between these traits and yield. Can. J. Plant Sci. 54:749-754.

White, J.W., and S.P. Singh. 1991. Breeding for adaptation to drought, p. 501-560. In: A. Van Schoonhoven and O. Voysest (ed.), Common beans: research for crop improvement. Wallingford, U.K.

Wilson, D. 1971. Selection responses of stomatal length and frequency, epidermal ridging, and other leaf characteristics in Lolium perenne $\mathrm{L}$. 'Grasslands Ruanui'. N.Z.J. Agr. Res. 14:761-771.

Wilson, D. 1972. Effect of selection for stomatal length and frequency on theoretical stomatal resistance to diffusion in Lolium perenne. L. New Phytol. 71:811-817.

Woodward, J. 1699. Some thoughts and experiments concerning vegetation. Philosoph. Trans. R. Soc. London 21:193-227.

Wright, L.N. 1975. Improving range grasses for germination and seedling establishment under stress environments, p. 3-22. In: R.S. Campbell and C.H. Herbel (ed.), Improved range plants. Soc. Range Manage. Symp. Series No. 1. Denver, Colo. 